\section{Assessment of the effect of cigarette smoking on the different denture base material}

\author{
Ashish Pandey*, Neeraja B, Himanshu Joshi, Deepti Upadhyay \\ and Sonam Pandey
}

Smile Care Dental Clinic \& Research Centre, Lucknow, UP, India

\section{Abstract}

Background: The present study was conducted to assess effect of cigarette smoking on different denture base material.

Materials \& Methods: The present study was conducted in the department of Prosthodontics. A total of sixty wax specimens in the shape of circular discs were prepared. These were divided into two groups. Group I (30) specimens were heat-cured denture base materials and group II (30) specimens were flexible denture base materials. Both specimens were further divided into four subgroups of 15 each. Subgroup I was heat-cured denture base material specimens (control group), subgroup II was flexible denture base material specimens (control group), subgroup III was heat-cured denture base material specimens exposed to cigarette smoking (study group) and subgroup IV was flexible denture base material specimens exposed to cigarette smoking (study group). The initial (IRa) and final (FRa) surface roughness was measured before and after smoking test of the specimens.

Results: It was observed that in group I, mean IR $(\mu \mathrm{m})$ value was 0.182 and FR value was 0.572. In group II, mean IR $(\mu \mathrm{m})$ value was 0.265 and FR value was 0.831 . In group III, mean IR $(\mu \mathrm{m})$ value was 0.195 and $F R$ value was 1.892. In group IV, mean IR $(\mu \mathrm{m})$ value was 0.291 and FR value was 1.892. The difference was significant $(P<0.05)$.

Conclusion: The surface roughness of the specimens fabricated from the flexible denture base material was found to be more compared to heat-cured denture base specimens after exposure to cigarette smoke. There is need to educate the patients regarding cleanliness of denture to avoid infection in the oral cavity.

\section{More Information}

*Address for Correspondence: Ashish Pandey, Smile Care Dental Clinic \& Research Centre, Lucknow, UP, India, Tel: +916387663821; Email: ashishpande26@yahoo.co.in

Submitted: 15 July 2019
Approved: 12 August 2019
Published: 13 August 2019

How to cite this article: Pandey A, Neeraja B, Joshi H, Upadhyay D, Pandey S. Assessment of the effect of cigarette smoking on the different denture base material. J Oral Health Craniofac Sci. 2019; 4: 008-011.

DOI: 10.29328/journal.johcs.1001027

Copyright: (c) 2019 Pandey A, et al. This is an open access article distributed under the Creative Commons Attribution License, which permits unrestricted use, distribution, and reproduction in any medium, provided the original work is properly cited

Keywords: Cigarette; Denture base; Surface roughness

Check for updates

\section{Introduction}

Among various denture material used in the fabrication denture, the heat-cured polymethylmethacrylate (PMMA) polymers are the most popular choice as conventional denture base materials for nonmetallic denture fabrication since its inception in 1937 [1]. Factors such as favourable physical and mechanical properties in terms of inexpensiveness, less solubility, decreased water sorption, optically clear (transparent) thermoplastic, and it is widely used as a substitute for inorganic glass, because it shows high impact strength, is lightweight, shatter-resistant, and exhibits favorable processing conditions. Outstanding properties include weather resistance and scratch resistance. And ease fabrication of denture bases by simple processing techniques make this material as first choice amongst dentists. However, apart from its vast favourable properties it has drawback such as polymerization shrinkage, weak flexural, lower impact strength, and low fatigue resistance. These often lead to denture failure during chewing or when fall out of the patient's hand, inducing hypersensitivity reactions because of presence of residual methyl methacrylate monomer [2].

The clinician skill of selecting denture base resins material is evenly significant along with designing and fabrication of a prosthesis to ensure long term survival rate of denture. Other useful material is Nylon (Polyamide resin) which was introduced in 1950. It is a type of thermoplastic polymer which is produced by the condensation reactions between a diamine and a dibasic acid. Nylon is a generic name for certain types of thermoplastic polymers belonging to the class known as polyamides. Nylon is a crystalline polymer. 
PMMA is amorphous in nature. The crystalline effect shows properties such as insolubility of nylon in solvents, high heat resistance, and high strength with ductility, it has have other advantages including higher elasticity than common heat-polymerizing resins, toxicological safety for patients with resin monomer and metal allergy, Cigarette smoking is seen not only amongst males but also females. Burning of cigarettes causes production of harmful gases which are harmful for soft tissues as well as for denture [3].

The denture base materials are exposed to thousands of cigarette toxic substances such as ammonia, nickel, arsenic, carbon monoxide, formaldehyde, radioactive polonium, tar, and heavy metals. It has deleterious effects on surface roughness, color, and microhardness of various dental restorative materials [4]. The present study was conducted to assess effect of cigarette smoking on different denture base material.

\section{Materials and Methods}

The present study was conducted in the department of Prosthodontics. The study protocol was approved from institutional ethical committee.

A stainless steel mold with circular shape of $25 \mathrm{~mm} \times$ $2 \mathrm{~mm}$ size for the preparation of acrylic disc specimens was prepared. Modeling wax was poured in the mold, and sixty wax specimens in the shape of circular discs were prepared. These were divided into two groups. Group I (30) specimens were heat-cured denture base material (Ultra-Hi Heat Cure Denture Base). A High Impact heat cure acrylic resin that exudes quality Short or long curing methods gives perfect results Superior flexural strength gives patients the assurance of quality and satisfaction and group II (30) specimens were flexible denture base materials (Valplast flexible partial denture). This type of denture is very light, durable and comes in a range of colours which are designed to match your gum tissue. It is hypo-allergenic and blends in well with the natural movement of your mouth.

In both groups surface roughness test was done. All the specimens in both groups were immersed in distilled water at $37^{\circ} \mathrm{C} \pm 1^{\circ} \mathrm{C}$ for $48 \mathrm{~h}$ for residual monomer release. After incubation period, the specimens were dried with air, and initial surface roughness was measured for the polished surface of all specimens. The initial surface roughness values were measured using a pick-up-type piezoelectric profilometer.

Both specimens were further divided into four subgroups of 15 each. Subgroup I was heat-cured denture base material specimens (control group), subgroup II was flexible denture base material specimens (control group), subgroup III was heat-cured denture base material specimens exposed to cigarette smoking (study group) and subgroup IV was flexible denture base material specimens exposed to cigarette smoking (study group).
The control subgroup (I and II) specimens were immersed in artificial saliva for 21 days and smoke test subgroup (III and IV) specimens were subjected to smoking in a custom-made smoking chamber partially filled with artificial saliva for 21 days before measurement of final surface roughness.

All the specimens were removed after the exposure to smoke and were washed with distilled water and dried. The final surface roughness (FRa) was measured using a profilometer. The initial (IRa) and final (FRa) surface roughness was measured before and after smoking test of the specimens. Results thus obtained were subjected to statistical analysis. P value less than 0.05 was considered significant.

\section{Results}

Table 1 shows distribution of 15 specimens in subgroup I, II, III and IV.

Table 2 shows initial and final roughness values of all specimens.

Table $3 \&$ Graph 1 shows that in group I, mean IR $(\mu \mathrm{m})$ value was 0.182 and FR value was 0.572 . In group II, mean IR $(\mu \mathrm{m})$ value was 0.265 and FR value was 0.831 . In group III, mean IR $(\mu \mathrm{m})$ value was 0.195 and FR value was 1.892 . In group IV, mean IR $(\mu \mathrm{m})$ value was 0.291 and FR value was 1.892. The difference was significant $(\mathrm{P}<0.05)$.

Graph I Mean IR and FR values of all specimens.

\begin{tabular}{|c|c|c|c|c|}
\hline Table 1: Distribution of specimens. \\
\hline Subgroups & $\begin{array}{c}\text { Subgroup I } \\
\text { (Control) }\end{array}$ & Subgroup II & Subgroup III & Subgroup IV \\
\hline Material & $\begin{array}{c}\text { heat-cured } \\
\text { denture base }\end{array}$ & $\begin{array}{c}\text { flexible } \\
\text { denture base }\end{array}$ & $\begin{array}{c}\text { heat-cured + } \\
\text { cigarette smoking }\end{array}$ & $\begin{array}{c}\text { flexible denture base } \\
\text { + cigarette smoking }\end{array}$ \\
\hline Number & 15 & 15 & 15 & 15 \\
\hline
\end{tabular}

Table 2: Surface roughness values of all specimens.

\begin{tabular}{l|l|l|l} 
Subgroup I $(\mu \mathrm{m})$ & Subgroup II $(\mu \mathrm{m})$ & Subgroup III $(\mu \mathrm{m})$ & Subgroup IV $(\mu \mathrm{m})$
\end{tabular}

\begin{tabular}{|c|c|c|c|c|c|c|c|}
\hline IR & FR & IR & FR & IR & FR & IR & FR \\
\hline 0.161 & 0.523 & 0.213 & 0.712 & 0.214 & 1.021 & 0.214 & 1.982 \\
\hline 0.156 & 0.624 & 0.245 & 0.724 & 0.241 & 0.902 & 0.245 & 1.892 \\
\hline 0.162 & 0.543 & 0.215 & 0.745 & 0.210 & 0.987 & 0.215 & 2.001 \\
\hline 0.212 & 0.612 & 0.234 & 0.654 & 0.213 & 1.021 & 0.321 & 2.013 \\
\hline 0.167 & 0.513 & 0.267 & 0.745 & 0.212 & 1.023 & 0.324 & 1.978 \\
\hline 0.192 & 0.624 & 0.234 & 0.785 & 0.211 & 1.012 & 0.312 & 1.908 \\
\hline 0.213 & 0.546 & 0.268 & 0.761 & 0.235 & 0.986 & 0.268 & 1.892 \\
\hline 0.164 & 0.657 & 0.265 & 0.654 & 0.265 & 0.956 & 0.315 & 1.923 \\
\hline 0.193 & 0.514 & 0.265 & 0.768 & 0.215 & 1.034 & 0.314 & 1.457 \\
\hline 0.183 & 0.656 & 0.298 & 0.765 & 0.298 & 1.023 & 0.298 & 1.213 \\
\hline
\end{tabular}

\begin{tabular}{|c|c|c|c|}
\hline \multicolumn{4}{|c|}{ Table 3: Mean IR and FR values of all specimens. } \\
\hline Groups & IR $(\boldsymbol{\mu m})$ & FR $(\boldsymbol{\mu m})$ & P value \\
\hline Group I & 0.182 & 0.572 & 0.01 \\
\hline Group II & 0.265 & 0.831 & 0.02 \\
\hline Group III & 0.195 & 1.234 & 0.01 \\
\hline Group IV & 0.291 & 1.892 & 0.05 \\
\hline
\end{tabular}




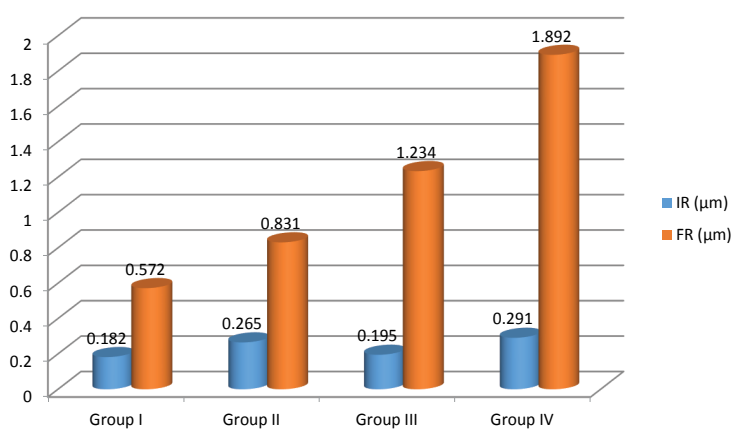

Graph 1: Mean IR and FR values of all specimens.

\section{Discussion}

PMMA is the commonly used material for the fabrication of removable prosthesis. Incorporation of metal fillers into poly-methylmethacrylate (PMMA) is difficult and techniquesensitive, with risk of toxicity [5]. The most recent preference in denture materials has been the use of nylon-like material for the fabrication of removable dental appliances. This material generally replaces the metal and the methyl methacrylate denture base material used for standard removable partial dentures. It is nearly unbreakable, esthetically acceptable, and can be fabricated quite thin sections [6].

Fibers are easier to incorporate in resin matrix and exhibit good bonding if treated with a coupling agent. Fibers reinforcement is dependent on many variables like type of fibers, percentage in matrix, modulus and distribution of fibers, length, orientation, and form [7]. The present study was conducted to assess effect of cigarette smoking on different denture base material.

In present study, specimens were divided into four subgroups of 15 each. Subgroup I was heat-cured denture base material specimens (control group), subgroup II was flexible denture base material specimens (control group), subgroup III was heat-cured denture base material specimens exposed to cigarette smoking (study group) and subgroup IV was flexible denture base material specimens exposed to cigarette smoking (study group).

Singh et al. [8], included a total numbers of 40 specimens which were fabricated from two commercially available denture base materials: heat-cured polymethylmethacrylate and flexible denture base materials ( 20 for each). The control groups were used for immersion in distilled water, and the smoke test groups were used for exposure to cigarette smoking. The smoke test group specimens were exposed to smoking in a custom-made smoking chamber using six cigarettes for each specimen. The surface roughness was measured using a profilometer, and the measurements were considered as the difference between the initial and final roughness measured before and after smoking. There was significant difference between initial surface roughness and final surface roughness within each subgroup.
We found that in group I, mean IR $(\mu \mathrm{m})$ value was 0.182 and FR value was 0.572 . In group II, mean IR $(\mu \mathrm{m})$ value was 0.265 and FR value was 0.831 . In group III, mean IR $(\mu \mathrm{m})$ value was 0.195 and FR value was 1.892. In group IV, mean IR $(\mu \mathrm{m})$ value was 0.291 and $F R$ value was 1.892 . The difference was significant $(\mathrm{P}<0.05)$.

The number of smokers has increased significantly in last few years. Smoking in the form of cigarette is the leading cause of tobacco related lesions in the oral cavity. India is the fourth largest consumer of tobacco and the third largest producer of tobacco in the world. There are about 250 million tobacco users in India, which accounts for about $19 \%$ of the world's 1.3 billion tobacco users [9].

During smoking there is release of nicotine, ammonia, nickel, arsenic, carbon monoxide, carbon dioxide, tar, and heavy metals which are active component of cigarette. During cigarette smoking, there is temperature change seen in the oral cavity. During exposure to smoke, all the specimens were also placed in artificial saliva to simulate intraoral conditions [10]. It was found that those specimens which were exposed to cigarette smoke showed surface roughness due to accumulation of tobacco products. The limitation of the study is that small sample size was selected.

\section{Conclusion}

Authors found that the surface roughness (high porosity, high water absorption, volume changes, and a lot of residual monomer) of the specimens fabricated from the flexible denture base material was found to be more compared to heat-cured denture base specimens after exposure to cigarette smoke. There is need to educate the patients regarding cleanliness of denture to avoid infection in the oral cavity.

\section{References}

1. Mahross HZ, Mohamed MD, Hassan AM, Baroudi K. Effect of cigarette smoke on surface roughness of different denture base materials. $J$ Clin Diagn Res. 2015; 9: ZC39-42.

PubMed: https://www.ncbi.nlm.nih.gov/pubmed/26501010

2. Vivek R. Polyamide as a denture base material. J Dent Med Sci. 2016; 15: 119-121.

PubMed: https://www.ncbi.nlm.nih.gov/pmc/articles/PMC4476124/

3. Peter S. Essential of Preventive and Community Dentistry. 4th ed. Arya Medi Publishing House, New Delhi. 2009.

4. Singh K, Gupta N. Injection molding technique for fabrication of flexible prosthesis from flexible thermoplastic denture base materials. World J Dent. 2012; 3: 303-307.

5. Pereira-Cenci T, Del Bel Cury AA, Crielaard W, Ten Cate JM. Development of candida-associated denture stomatitis: New insights. J Appl Oral Sci. 2008; 16: 86-94

PubMed: https://www.ncbi.nlm.nih.gov/pubmed/19089197

6. Casemiro AL, Gomes Martins $\mathrm{CH}$, Pires-de-Souza Fde C, Panzeri $\mathrm{H}$. Antimicrobial and mechanical properties of acrylic resin with incorporated siler-zinc zeolite-part I. Gerodontology. 2008; 25:187-194. PubMed: https://www.ncbi.nlm.nih.gov/pubmed/18194331 
7. Thumati P, Padmaja S, Reddy R. Flexible denture in prosthodontics An overview. Indian J Dent Adv. 2013; 5: 1380-1385.

8. Singh G, Agarwal A, Lahori M. Effect of cigarette smoke on the surface roughness of two different denture base materials: An in vitro study. $J$ Indian Prosthodont Soc. 2019; 19: 42-48.

PubMed: https://www.ncbi.nlm.nih.gov/pubmed/30745753

9. Dos Bertoldo CE, Miranda D de A, Souza-Júnior EJ, Aguiar FHB, Lima
DANL, et al. Surface hardness and color change of dental enemal exposed to cigarette smoke. Int J Dent Clin. 2011; 3: 1-4.

10. Mathias P, Silva LD, Saraiva Lde O, Costa L, Sampaio MD, et al. Effect of surface sealant and repolishing procedures on the color of composite resin exposed to cigarette smoke. Gen Dent. 2010; 58: 331-335. PubMed: https://www.ncbi.nlm.nih.gov/pubmed/20591779 